\title{
The Essence of Criminal Responsibility for Perpetrators of Sexual Violence Against Girls with Disabilities
}

\author{
Nurisnah $\mathrm{H}^{1} \quad$ Muhammad Said Karim ${ }^{2} \quad$ Syamsuddin Muchtar $^{3} \quad$ Haeranah $^{3}$ \\ 1.Doctoral Student, Faculty of Law, Hasanuddin University, Indonesia \\ 2.Professor of Law, Faculty of Law, Hasanuddin University, Indonesia \\ 3.Associate Professor, Faculty of Law, Hasanuddin University, Indonesia
}

\begin{abstract}
Sexual violence against girls with disabilities is a crime against human dignity and a violation of human rights. Children with disabilities should get better protection from parents, society and the government. This study will examine the nature of criminal responsibility for perpetrators of sexual violence against girls with disabilities. This research is a normative research with a legal and philosophical approach. The results show that the essence of criminal responsibility for perpetrators of sexual violence against girls with disabilities is as a form of legal protection, the application of sanctions against perpetrators and protection from the community is the basic core of respect, promotion, protection, and fulfillment of the dignity of girls with disabilities who become victims of sexual violence.
\end{abstract}

Keywords:Criminal Responsibility, Sexual Violence, Girls with Disabilities

DOI: $10.7176 / \mathrm{JLPG} / 115-05$

Publication date: November $30^{\text {th }} 2021$

\section{A. Introduction}

Protection of children in a society, nation and state is a measure of the welfare and prosperity of the community, nation and state concerned. For this reason, it is our collective obligation to the government and every member of the community, both individually and collectively, to seek the protection of children according to their capabilities for the common interest, national interest and humanitarian interest. ${ }^{1}$ Child protection must be reflected and realized in various community lives, not only covering the protection of the child's soul, but also including the protection of their rights and interests. The legal aspects of child protection need to be considered because legal protection against children and juvenile justice is one way to protect children in their future growth. ${ }^{2}$

The crime of child sexual violence that is currently seizing the attention of the community. ${ }^{3}$ Data from the Central Statistics Agency (BPS) processed by the Ministry of Health's Data and Information Center, the estimated number of children in Indonesia for 2018 is $33 \%$ of the total estimated population $(88,312,971$ for ages 0-18 years), almost evenly distributed in the age range $0-2$ years to $12-14$ years is about $16 \%$ and $15-18$ years old dominates about $20 \%$ of children's age. Meanwhile, based on gender, that is $49 \%$ female and $59 \%$ male. From these estimates illustrate the potential of the young generation that is quite large in the future. For this reason, children and adolescents need to have the widest opportunity to grow and develop optimally, physically, mentally, socially, and with noble character. But on the other hand, it warns that Indonesia also has a large potential risk for cases of violence involving children. ${ }^{4}$

Children with disabilities are children who have physical, mental, intellectual, and/or sensory limitations in the long term who in interacting with the environment and the attitudes of the community may encounter obstacles that make it difficult to participate fully and effectively on the basis of equal rights. ${ }^{5}$ Children with disabilities also have the same needs as other children, but children with disabilities need more assistance because their physical, mental, intellectual and sensory limitations are different from children in general. Meeting the special needs of persons with disabilities must be carried out within the family and society in general. ${ }^{6}$ Protection of children with disabilities requires institutional support and legislation that guarantees its

\footnotetext{
${ }^{1}$ Fadhilah, F. (2020). Tindak Pidana Pelecehan Seksual Oleh Anak Di Bawah Umur Menurut Uu No. 35 Tahun 2015 (Kajian Kasus di Mahkamah Syar'iyah). SYARIAH: Journal of Islamic Law, 2(2), 88-119.

${ }^{2}$ Aksan, Karim, M. Said., \& Asis, Abdul. (2020). Legal assistance agencies for children as criminal action victims in criminal justice processes. Jurnal Cakrawala Hukum, 11(3), 313-322. See also, Bakhtiar, H. S., Sofyan, A. M., \& Haeranah, H. (2019). Criminal Justice System of Children in Indonesia. IOSR Journal Of Humanities And Social Science (IOSR-JHSS) Volume, $24,01-07$.

${ }^{3}$ Anugrianti, A. D., Muchtar, S., \& Azisa, N. (2019). The Concept Of Imposing Criminal Sanctions For Perpetrators Of Child Sexual Violence: The Deterrent Effect. European journal of law and political sciences, (3), 14-19.

${ }^{4} \mathrm{https}: / /$ www.kemkes.go.id/, accessed on 8 October 2019.

${ }^{5}$ Widinarsih, D. (2019). Penyandang disabilitas di indonesia: perkembangan istilah dan definisi. Jurnal Ilmu Kesejahteraan Sosial (Journal of Social Welfare), 20(2). See also, Andriani, N. S. (2017). Kebijakan Responsif Disabilitas: Pengarusutamaan Managemen Kebijakan Di Level Daerah, Nasional Dan Internasional. Palastren Jurnal Studi Gender, 9(1), 189-214.

${ }^{6}$ Firdaus, F., \& Iswahyudi, F. (2010). Aksesibilitas Dalam Pelayanan Publik Untuk Masyarakat Dengan Kebutuhan Khusus. Jurnal Borneo Administrator, 6(3).
} 
implementation.

The current regulations, although children's rights have been regulated, have not been able to accommodate the rights of girls and women with disabilities who are victims of sexual violence. Victims of crime who are basically the party who suffers the most in a crime, actually do not get the maximum protection provided by law to the perpetrator. Nevertheless, special forms of protection that can be given to child victims of criminal acts are carried out through rapid treatment, including physical, psychological and social treatment and/or rehabilitation, as well as prevention of disease and other health disorders, psychosocial assistance during treatment up to period of treatment, recovery, providing social assistance for children who come from underprivileged families as well as providing protection and assistance in every judicial process. Special protection for child victims of sexual crimes carried out through efforts such as; 1. education about reproductive health, religious values, and moral values; 2. Social rehabilitation for children; 3 . Psychosocial assistance during treatment until recovery; and 4. Provide protection and assistance at every level of examination, starting from the investigation process, prosecution, to the examination process in court. In addition to the special protection rights granted to children who are victims of criminal acts, they also have the right to apply for restitution which is the responsibility of the perpetrators of the crime However, not all children who are victims of criminal acts have this right. Those who are entitled to apply for court restitution are:

1) Children as victims of economic and or sexual exploitation;

2) Children as victims of pornography crimes;

3) Children as victims of criminal acts of kidnapping, selling, and/or trafficking in persons;

4) Children as victims of criminal acts of physical and/or psychological violence;

5) Children are victims of sexual crimes.

Special Protection is carried out through the following efforts:

a) Immediate treatment, including physical, psychological, and social treatment and/or rehabilitation, as well as prevention of diseases and other health disorders;

b) Psychosocial assistance during treatment to recovery;

c) Providing social assistance for children from underprivileged families; and

d) Provide protection and assistance in every judicial process.

This has been regulated in Indonesian law in the form of laws and regulations, including Law No. 35 of 2014 concerning Amendments to Law No. 23 of 2002 concerning Child Protection and Law No. 8 of 2016 concerning Persons with Disabilities. This law is regulated in the form of provisions regarding the protection of children, both for their rights and for the child's own person.

Based on the data, the most prominent type of violence against women, the same as the previous year, was domestic violence (personal) which reached $71 \%(9,637)$. The private sector was the most reported and not a few of them experienced sexual violence. The second position of violence against children is in the realm of the public community with a percentage of $28 \%(3,915)$ and the last is in the realm of the state with a percentage of $0.1 \%(16)$. In the realm of domestic violence, the most prominent violence was physical violence, 3,927 cases $(41 \%)$, ranked first, followed by sexual violence with 2,988 cases $(31 \%)$, psychological violence $1,658(17 \%)$ and economic 1,064 cases $(11 \%) .{ }^{1}$ From this data it is clear that sexual violence that occurs in children ranks second and of course must receive special attention, starting from the protection of children's rights as victims and legal responsibility for the perpetrators. In addition, if the child is a girl who is a vulnerable group to experience violence. This is even more so if the one who experiences/ becomes the victim is a girl who has limitations (persons with disabilities). Sexual crimes committed against children will have a psychological impact on the child, in the form of mental and emotional state disorders. ${ }^{2}$

The limitations of girls with disabilities make it difficult for them to protect themselves from all forms of violence, including sexual violence. Girls with disabilities who are victims of violence often find it difficult to get justice for the wrong treatment they experience, especially if the perpetrator is someone close to them. ${ }^{3}$ In addition, when a girl with a disability experiences a bad incident (sexual violence), she may be silent and not refuse and fight because of her powerlessness. Usually, they also cannot distinguish what is good and what is bad, decency or sin, may or may not and others.

Violence against girls is one of the problems that has a high level of urgency in modern life. ${ }^{4}$ Violence against girls can be said as the treatment of adults/elderly against girls by using their power/authority against a helpless child who should be the responsibility of the caregiver, which results in suffering, misery, disability or

\footnotetext{
${ }^{1}$ https://www.komnasperempuan.go.id/file/CatataTahunanKekerasanTerhadapPerempuan2019.pdf accessed on 17 October 2019.

${ }^{2}$ Jannah, S. H. M., Muchtar, S., \& Mirzana, H. A. (2021). Restitution rights for children of victims of sexual crimes: between protection and reresting. Jurnal Cakrawala Hukum, 12(2), 223-232.

${ }^{3}$ Wiarti, J. (2020). Kompleksitas Persoalan Pemenuhan Hak Penyandang Disabilitas di Pengadilan Negeri Pekanbaru. Jurnal Hukum Ius Quia Iustum, 27(1), 87-109.

${ }^{4}$ Rahmi, A. (2018). Urgensi Perlindungan Bagi Korbankekerasan Seksual Dalam Sistem Peradilan Pidana Terpadu Berkeadilan Gender. Jurnal Mercatoria, 11(1), 37-60.
} 
death. ${ }^{1}$ All forms of inappropriate actions against children with disabilities are often carried out by those closest to the victim, such as family members, although it is possible that people who do not even know the victim may also do it. ${ }^{2}$ Apart from all that, parents have a very important role to minimize this incident. Where parents are the first to be responsible for the realization of children's welfare both spiritually, physically, and socially. ${ }^{3}$ For this reason, this study will examine the criminal responsibility of perpetrators of sexual violence against girls with disabilities.

\section{B. Methods of Research}

This research is a normative ${ }^{4}$ research with statutory and philosophical approach. The research material was analyzed using descriptive methods and providing prescriptive arguments. ${ }^{5}$

\section{Results and Discussion}

\section{Protection of Children as Victims of Sexual Violence}

One of the instruments used in child protection is law. Legal protection for children can be interpreted as legal protection efforts against various violence and violations of children's rights as well as various efforts related to child welfare. $^{6}$

According to Arief Gosita, child protection is an effort to provide conditions and situations that allow the implementation of children's rights and obligations in a humane manner. ${ }^{7}$ herefore, every child's rights must be upheld for the sake of achieving a goal, namely the birth of a healthy young generation for the survival of the nation's life.

In principle, child protection based on Law No. 35 of 2014 which was carried out based on Pancasila and the 1945 Constitution of the Republic of Indonesia. The principle of protection is regulated based on the best interest of the child, where this principle stipulates that all actions concerning children are carried out by the government, society, legislative bodies and judiciary, which is based on the interests of the child must be the main consideration.

Law No. 31 of 2014 which is an amendment to Law no. 13 of 2006 concerning the Protection of Witnesses and Victims which has been ratified by the government and promulgated to correct the weaknesses in Law no. 13 of 2006, especially for the legal protection of children. The state paid attention by passing Law No. 35 of 2014 concerning Amendments to Law No. 23 of 2002 concerning Child Protection. These changes are to emphasize the importance of weighting criminal sanctions and also fines for perpetrators of crimes against children, to provide a deterrent effect, and to encourage concrete efforts to restore physical, psychological and social conditions for children as victims or perpetrators of the same crime in the future. ${ }^{8}$

Children who are victims of sexual violence are entitled to special protection. ${ }^{9}$ What is specifically meant is a form of protection that can be accepted by a child in certain situations and conditions for a child to get a guarantee of a sense of security against threats that can endanger him and his soul in their growth and development. ${ }^{10}$ Crime victims who are basically the ones who suffer the most in a criminal act, actually do not get as much protection given by the law to perpetrators. ${ }^{11}$

Special forms of protection that can be given to children who are victims of a criminal act carried out through rapid treatment, including physical, psychological, and social treatment and/or rehabilitation, as well as prevention of disease and other health disorders, psychosocial assistance during treatment until the time of treatment. recovery, providing social assistance for children who come from underprivileged families and providing protection and assistance in every judicial process. ${ }^{12}$

Special protection for child victims of sexual crimes committed through the following efforts: ${ }^{13}$

1. Education regarding reproductive health, religious values, and moral values;

\footnotetext{
${ }^{1}$ Sianipar, S. R. (2019). Penerapan Hukum Terhadap Pelaku Kekerasan Anak yang Mengakibatkan Kematian Berdasarkan Undang-Undang Nomor 35 Tahun 2014 Tentang Perlindungan Anak (Studi Kasus Putusan No. 560/Pid. Sus/2016/PN. Mdn). Universitas Medan Area.

${ }^{2}$ Wulandari, R., \& Suteja, J. (2019). Konseling Pendidikan Seks dalam Pencegahan Kekerasan Seksual Anak (KSA). Prophetic: Professional, Empathy and Islamic Counseling Journal, 2(1), 61-82.

${ }^{3}$ Mumu, V. A. J. (2019). Tinjauan Yuridis Tentang Tanggung Jawab Orang Tua Terhadap Anak Setelah Perceraian Dalam Uu No 1 1974

Pasal 45 Ayat (1). Lex Privatum, 6(8).

${ }^{4}$ Soekanto, S., \& Mamudji, S. (2014). Penelitian Hukum Normatif Suatu Tinjauan Singkat, cet. 16. Jakarta: Rajawali Pers. p. 13

${ }^{5}$ Irwansyah. (2020). Penelitian hukum : pilihan metode \& praktik penulisan artikel. Yogyakarta: Mirra Buana Media

${ }^{6}$ Pangemanan, J. B. (2015). Pertanggungjawaban Pidana Anak dalam Sistem Peradilan Pidana Indonesia. Lex et Societatis, 3(1).

${ }^{7}$ Erdianti, R. N., \& Fatih, S. M. (2019). Mewujudkan Desa Layak Anak Sebagai Bentuk Perlindungan Hukum Terhadap Anak Di Indonesia. Justitia Jurnal Hukum, 3(2).

${ }^{8}$ Explanation of Law No. 35 of 2014.

${ }^{9}$ Article 59 Paragraph (2) Law No. 35 of 2014

${ }^{10}$ Article 1 Number (15) Law No. 35 of 2014.

${ }^{11}$ Nur, F., Akub, M. S., Karim, M. S., \& Muchtar, S. (2019). Legal Protection of Victim Rights against Human Trafficking in the Criminal Justice Process. JL Pol'y \& Globalization, 87, 139.

${ }^{12}$ Article 59A Law No. 35 of 2014

${ }^{13}$ Article 69A Law No. 35 of 2014
} 
2. Social rehabilitation for children;

3. Psychosocial assistance during treatment until recovery; and also

4. Providing protection and assistance at every level of examination, starting from the process of investigation, prosecution, to the examination process in court.

In addition to the special protection rights given to children who are victims of a crime, they also have the right to apply for restitution rights which are the responsibility of the perpetrators of the crime. ${ }^{1}$ However, not all children who are victims of a crime have this right, those who have the right to apply for court restitution are: ${ }^{2}$

1.Children as victims of being exploited economically and or sexually;

2.Children as victims of pornography crime;

3.Children as victims of criminal acts of kidnapping, selling, and/or trafficking;

4.Children as victims of criminal acts of physical and/or psychological violence;

5.Children are victims of sexual crimes.

Children's rights are very important to be protected, especially for children who are victims of sexual crimes. The sentencing of a perpetrator of a sexual crime does not eliminate the traumatic feelings suffered by the victim. ${ }^{3}$ Therefore, the existence of the victim's right to ask for restitution from the victim becomes an important point. Because this right of restitution is used to restore the trauma suffered by child victims of sexual crimes.

The rights of children who are victims of sexual violence are given and protected by the state and are regulated in several laws including Law No. 35 of 2014, Law No. 31 of 2014, Law No. 11 of 2012, and specifically for persons with disabilities, it is regulated in Law No. 8 of $2016 .{ }^{4}$

Table 1. Comparison of Child Protection Victims of Sexual Violence in Law No. 31 of 2014, Law No. 11 of 2012, and Law No. 35 of 2014.

\begin{tabular}{|c|c|c|c|c|}
\hline \multirow[t]{2}{*}{ NO } & & \multicolumn{3}{|c|}{ Comparison of Child Protection Victims of Sexual Violence } \\
\hline & & Law No. 31 of 2014 & Law No. 11 of 2012 & Law No. 35 of 2014. \\
\hline & $\begin{array}{l}\text { Rights } \\
\text { And } \\
\text { Protected }\end{array}$ & $\begin{array}{l}\text { Article } 5 \\
\text { a. Obtain protection for } \\
\text { the security of his } \\
\text { personal, family, and } \\
\text { property, as well as } \\
\text { being free from threats } \\
\text { related to the testimony } \\
\text { that he will, is currently, } \\
\text { or has given; } \\
\text { b. Participate in the } \\
\text { process of selecting and } \\
\text { also determining the } \\
\text { form of protection and } \\
\text { support for a security; } \\
\text { c. Give a statement } \\
\text { without any pressure; } \\
\text { d. Translator services; } \\
\text { e. Free from questions } \\
\text { that can ensnare; } \\
\text { f. Obtain all information } \\
\text { regarding the progress of } \\
\text { the case; } \\
\text { g. Obtain all information } \\
\text { regarding } \\
\text { decisions; } \\
\text { h. Obtain all information } \\
\text { in the event that the } \\
\text { convict is released; }\end{array}$ & $\begin{array}{l}\text { Article 9, 60, 61, 89, } \\
\text { 90, 97. } \\
\text { a. His identity is not } \\
\text { published; } \\
\text { b. Obtain assistance } \\
\text { from parents/guardians } \\
\text { and people who are } \\
\text { trusted by the child; } \\
\text { c. Obtaining health } \\
\text { services; and } \\
\text { d. Obtain other rights } \\
\text { in accordance with the } \\
\text { provisions of the } \\
\text { legislation } \\
\text { e. The right to } \\
\text { participate in the } \\
\text { diversion process } \\
\text { f. In certain cases, the } \\
\text { victim's child is given } \\
\text { the opportunity by the } \\
\text { judge to express his } \\
\text { opinion on the case in } \\
\text { question; } \\
\text { g. } \\
\text { rehabilitation } \\
\text { social rehabilitation } \\
\text { efforts, both within the } \\
\text { institution and outside }\end{array}$ & $\begin{array}{l}\text { Article 69, } 71 \\
\text { Special Protection, carried out through } \\
\text { efforts: } \\
\text { a. Prompt treatment, including } \\
\text { treatment and/or rehabilitation } \\
\text { physically, psychologically, and } \\
\text { socially, as well as prevention of } \\
\text { disease and other health problems; } \\
\text { b. Psychosocial assistance during } \\
\text { treatment until recovery; } \\
\text { c. Providing social assistance for } \\
\text { children who come } \\
\text { underprivileged families; and } \\
\text { d. Providing protection and assistance } \\
\text { in every judicial process. } \\
\text { Special protection for child victims of } \\
\text { sexual crimes is carried out through } \\
\text { the following efforts: } \\
\text { a. Education on reproductive health, } \\
\text { religious values, and moral values; } \\
\text { b. Social rehabilitation; } \\
\text { c. Psychosocial assistance during } \\
\text { treatment until recovery; and } \\
\text { d. Providing protection and assistance } \\
\text { at every level of examination starting } \\
\text { from investigation, prosecution, to } \\
\text { examination in court. }\end{array}$ \\
\hline
\end{tabular}

\footnotetext{
${ }^{1}$ Haeranah, H., \& Amriyanto, A. (2020). Ganti Kerugian dan Rehabilitasi Bentuk Perlindungan Terhadap Korban Tindak Pidana dan Korban Proses Penegakan Hukum di Indonesia. de Jure Jurnal Ilmiah Ilmu Hukum, 2(1), 68-82.

${ }^{2}$ Article 71D Paragraph (1) Law No. 35 of 2014.

${ }^{3}$ Yulia, R. (2010). Viktimologi: Perlindungan Hukum Terhadap Korban Kejahatan. Yogyakarta: Graha Ilmu. p.14

${ }^{4}$ Nur, R., \& Bakhtiar, H. S. (2020). The Imposition of Sanctions for Children. Hasanuddin Law Review, 6(2), 165-171. See also, Nur, R., Riza, M., Moenta, A. P., \& Bakhtiar, H. S. (2020). Sanctions on Children: Comparative Studies of Indonesia and Netherlands. JL Pol'y \& Globalization, 98, 225.
} 


\begin{tabular}{|c|c|c|}
\hline $\begin{array}{l}\text { i. All identities are kept } \\
\text { confidential; } \\
\text { j. Get a new identity; } \\
\text { k. Obtaining temporary } \\
\text { residence; } \\
\text { l. Get a new place of } \\
\text { residence; } \\
\text { m. Get reimbursement of } \\
\text { transportation costs as } \\
\text { needed } \\
\text { n. Get legal advice; } \\
\text { o. Get temporary living } \\
\text { expenses assistance until } \\
\text { the end of the protection } \\
\text { period; and/or } \\
\text { p. Get assistance } \\
\text { (additionally for victims } \\
\text { of severe human rights, } \\
\text { terrorism crimes, crimes } \\
\text { of trafficking in persons, } \\
\text { sexual violence and } \\
\text { serious mistreatment as } \\
\text { follows: } \\
\text { q. Get medical help; } \\
\text { r. Get rehabilitation, } \\
\text { psychosocial and and } \\
\text { psychological assistance; } \\
\text { s. Get compensation } \\
\text { (victims of serious } \\
\text { human rights violations } \\
\text { and victims of criminal } \\
\text { acts of terrorism in } \\
\text { addition to getting the } \\
\text { rights mentioned earlier, } \\
\text { are also entitled to } \\
\text { compensation) } \\
\text { t. Get refunds. }\end{array}$ & $\begin{array}{l}\text { the institution; } \\
\text { h. Health insurance, } \\
\text { both physical, mental, } \\
\text { and social; } \\
\text { i. Ease of obtaining } \\
\text { information regarding } \\
\text { the progress of the } \\
\text { case; } \\
\text { j. Social reintegration } \\
\text { from institutions or } \\
\text { agencies that handle } \\
\text { child protection } \\
\text { k. Obtain protection } \\
\text { from institutions that } \\
\text { handle witness and } \\
\text { victim protection or } \\
\text { social protection } \\
\text { houses. }\end{array}$ & $\begin{array}{l}\text { Special protection for economically } \\
\text { and/or sexually exploited children is } \\
\text { carried out through: } \\
\text { a. Dissemination and/or socialization } \\
\text { of the provisions of laws and } \\
\text { regulations relating to the protection } \\
\text { of economically and/or sexually } \\
\text { exploited children; } \\
\text { b. Monitoring, reporting, and } \\
\text { imposing sanctions; and } \\
\text { c. Involvement of various companies, } \\
\text { trade unions, non-governmental } \\
\text { organizations, and the community and } \\
\text { the elimination of economic and/or } \\
\text { sexual exploitation of children. } \\
\text { Special protection for children who } \\
\text { are victims of pornography is carried } \\
\text { out through: } \\
\text { a. Efforts for coaching, mentoring, as } \\
\text { well as social recovery, physical and } \\
\text { mental health. } \\
\text { b. Coaching, mentoring, and social } \\
\text { recovery, physical and mental health. } \\
\text { Right to get restitution } \\
\text { Every child who is a victim as referred } \\
\text { to in Article } 59 \text { paragraph ( } 2 \text { ) letter b } \\
\text { (Children in conflict with the law), } \\
\text { letter d (Children who are } \\
\text { economically and/or sexually } \\
\text { exploited), letter f (children who are } \\
\text { victims of pornography), letter h , } \\
\text { letter I (child victims of physical } \\
\text { and/or psychological violence), and } \\
\text { letter j (child victims of sexual crimes) } \\
\text { have the right to submit to the court } \\
\text { the right to restitution which is the } \\
\text { responsibility of the perpetrator of the } \\
\text { crime. }\end{array}$ \\
\hline
\end{tabular}

Based on the comparison table, it can be concluded that the rights of children as victims are the rights inherent in every child to get protection from the state, the right to obtain justice, and the right to have their welfare guaranteed. In this case, it is not only the role of the state that is needed to uphold the rights of children who are victims of sexual violence, but the community must also play a role. The participation of the state has been regulated by law. ${ }^{1}$

\section{Criminal Sanctions for Perpetrators of Sexual Violence Against Girls with Disabilities}

Law No. 35 of 2014 confirms the meaning of violence is any act against a child that results in physical, psychological, sexual misery or suffering and/or neglect, including threats to commit acts, coercion, or unlawful deprivation of liberty.

Violence as a crime in criminal law, the losses experienced by children as victims of violence have not been concretely regulated, meaning that criminal law that provides protection to children as victims is more of an abstract protection or indirect protection. ${ }^{2}$ The existence of various formulations of criminal acts in the legislation regarding sanctions and criminal liability is not aimed at protecting victims directly and concretely but only protecting victims indirectly and abstractly.

\footnotetext{
${ }^{1}$ Article 21-24 Law No. 35 of 2014

2 Alfian, A. (2015). Upaya Perlindungan Hukum Terhadap Korban Tindak Pidana Perdagangan Orang. Fiat Justisia: Jurnal Ilmu Hukum, 9(3).
} 
Sexual abuse, refers to any sexual activity, the form can be in the form of assault or without assault. ${ }^{1}$ for the category of assault that causes suffering in the form of physical injury, the category of sexual violence without assault is suffering from emotional trauma.

Forms of sexual violence such as seduction, forced hugs, squeezed, forced masturbation, oral sex, anal sex and rape. related to acts of sexual violence, regulated in the Criminal Code can be seen in Articles 281 to 287 , Article 289, Article 290, Article 294, Article 295.

Placing children as victims of crime in the discussion of legal protection for children can be found in the provisions of the Criminal Code which regulates several types of crimes that can be experienced by children, namely:

a. Intercourse

1. Article 287 of the Criminal Code:

a) whoever has sexual intercourse with a woman, outside of marriage, even though she knows or should reasonably suspect that she is not yet fifteen years old, or if her age is not clear, that it is not yet time for marriage, shall be punished by a maximum imprisonment of nine years.

b) prosecution is only carried out on a complaint, except if the woman is not yet twelve years old or if there is one of the things based on Article 291 and Article 294.

2. Article 288 of the Criminal Code:

a) Whoever in marriage has sexual intercourse with a woman whom he knows or should reasonably suspect that it is not yet time for him to marry, if the act results in injury, shall be punished by a maximum imprisonment of four years.

b) If the act results in serious injury, a maximum imprisonment of eight years is imposed.

c) If it results in death, a maximum imprisonment of twelve years is imposed.

3. Article 291 of the Criminal Code:

a) If one of the crimes under Article 286, Article 287, Article 289, and Article 290 results in serious injury, a maximum imprisonment of twelve years is imposed.

b) If one of the crimes under Article 285, Article 286, Article 287, Article 289, and Article 290 results in death, a maximum imprisonment of fifteen years is imposed.

b. Lewd act

1. Article 289 of the Criminal Code:

Anyone who by force or threat of violence forces someone to commit or allow an obscene act to be carried out, is threatened for committing an act that attacks the honor of morality, with a maximum imprisonment of nine years.

2. Article 292 of the Criminal Code:

An adult who commits an obscene act with another person of the same sex, which he knows or should reasonably suspect is a minor, is threatened with a maximum imprisonment of five years.

3. Article 293 of the Criminal Code:

a) Whoever by giving or promising money or goods, abuses the authority that arises from a relationship of circumstances or by misdirection, deliberately moves a minor and good in behavior to commit or allow it to be carried out in an obscene act with him, even though the matter of his immaturity is known or appropriate, he must alleged to be punishable by a maximum imprisonment of five years.

b) prosecution is only carried out on a person's complaint against him/her having committed the crime.

c) The grace period referred to in Article 74 for this complaint is nine months and twelve months, respectively.

4. Article 294 of the Criminal Code:

a) Anyone who commits an obscene act with his child who is not yet an adult, his stepson, his adopted child, a child under his supervision who is not yet an adult, or with a minor person whose care, education and care are left to him or his bachelor or subordinate who is not yet an adult, is threatened with imprisonment for a maximum of seven years.

b) Threatened with the same criminal sanction:

1) a civil servant who commits an obscene act with a person who because of his position is his subordinate or with a person whose care is entrusted or handed over to him;

2) administrators, doctors, staff teachers, supervisors or messengers in prisons, state places of work, places of education, orphanages, hospitals, mental hospitals or social institutions, who commit obscene acts with people who are admitted to them.

\footnotetext{
1 Rahmi, A. (2018). Urgensi Perlindungan Bagi Korbankekerasan Seksual Dalam Sistem Peradilan Pidana Terpadu Berkeadilan Gender. Jurnal Mercatoria, 11(1), 37-60.
} 
5. Article 295 of the Criminal Code:

a) Threatened:

1) With a maximum imprisonment of five years, any person who intentionally causes or facilitates an obscene act by his child, stepson, adopted child, or child under his supervision who is not yet an adult, or by an immature person whose care, education or care handed over to him, or by his underage or underage, by another person;

2) With a maximum imprisonment of four years whoever intentionally connects or facilitates obscene acts, except those referred to in point 1 above, which is committed by a person who he knows is not yet an adult or who he should reasonably suspect, with another person.

b) If the guilty commits the crime as a means of livelihood or habit, the punishment may be increased by one third.

6. Article 298 of the Criminal Code:

a) In the case of punishment based on one of the crimes in Article 281, Articles 284 to Article 290, and Articles 292 to Article 297, the revocation of rights based on Article 35 Numbers 1 to 5 can be stated.

b) If the guilty commits one of the crimes under Article 292 to Article 297 in carrying out his livelihood, then the right to do so can be revoked.

With regard to violence against girls with disabilities, the laws and regulations that can be applied in addition to the Criminal Code are Law of the Republic of Indonesia No. 35 of 2014. Looking at this legal instrument, which stipulates that perpetrators of acts of violence against children there are severe sanctions, so that perpetrators and other people do not do the same thing.

\section{The Community protection}

The community participates in child protection, both individually and in groups. ${ }^{1}$ The role of the community is carried out by individuals, child protection institutions, social welfare institutions, community organizations, educational institutions, mass media and the business world. The role of the community in the implementation of child protection is carried out by: ${ }^{2}$

1) Providing information through socialization and education regarding children's rights and laws and regulations regarding children

2) Provide input in the formulation of policies related to child protection

3) Reporting to the authorities if there is a violation of children's rights

4) Take an active role in the rehabilitation and social reintegration process for children

5) Monitoring supervision and taking responsibility for the implementation of child protection

6) Providing facilities and infrastructure and creating a conducive atmosphere for children's growth and development

7) Play an active role by eliminating the negative labeling of child victims as referred to in Article 59

8) Provide space for children to be able to participate and express opinions.

The role of the community is carried out in accordance with the provisions of the applicable laws and regulations. Responsibilities in terms of providing special protection to children as victims can also be seen according to Law no. 35 of 2014 Article 59 stipulates that the government and other state institutions are obliged and responsible to provide special protection to children, including children who are victims of sexual crimes, and children with disabilities. One of these special protections is given to children who are victims of sexual crimes.

The responsibility for child protection is sought by everyone, both parents, families, communities and the government Law No. 35 of 2014, Article 20 stipulates that the state, government, local government, community, family and parents or guardians are obliged and responsible for the implementation of child protection.

Every member of the community according to their abilities with various kinds of efforts in certain situations and conditions must seek child protection. ${ }^{3}$ Every citizen is responsible for the implementation of child protection for the welfare of the child. Children's happiness is shared happiness, protected happiness is protective happiness. There is no anxiety in children, because child protection is carried out properly and children become prosperous.

Child welfare has a positive influence on parents, family, community and government. Child protection benefits children and their parents, families, communities and governments. ${ }^{4}$ Coordination of cooperation in

\footnotetext{
${ }^{1}$ Tengker, O. R. (2021). Perlindungan Khusus Bagi Anak Korban Kekerasan Fisik Atau Psikis. Lex Privatum, 9(4).

${ }^{2}$ Article 72 Paragraph (3), Law No. 35 of 2014.

${ }^{3}$ Said, M. F. (2018). Perlindungan Hukum Terhadap Anak Dalam Perspektif Hak Asasi Manusia. JCH (Jurnal Cendekia Hukum), 4(1), 141152. See also, Supriyanto, B. H. (2015). Perlindungan Hukum Terhadap Anak Pelaku Perkosaan Berdasarkan Hukum Positif Indonesia. ADIL: Jurnal Hukum, 6(2), 147-181.

${ }^{4}$ Fitri, A. N., Riana, A. W., \& Fedryansyah, M. (2015). Perlindungan Hak-Hak Anak Dalam Upaya Peningkatan Kesejahteraan
} 
child protection activities needs to be carried out in order to prevent an imbalance in overall child protection activities.

The state has an obligation to protect all its citizens and it is natural for the state to pay more attention to victims of crime who may experience suffering, both economically, physically, and psychologically. ${ }^{1}$ The state also has a responsibility to provide welfare to its citizens. Therefore, when members of the community experience events that cause their welfare to be disturbed and become victims of crime, it is only natural that the state is responsible for restoring the welfare of its citizens, considering that the state has failed to provide welfare for its people.

Human behavior that is evil, immoral, and anti-social makes people angry and creates a sense of discomfort and calm in the community and is very detrimental to the public. Therefore, these crimes must not be allowed to continue to develop and grow in people's lives, so acts of sexual violence must be eradicated for the sake of order, security, and public safety. The community as a whole, together with the authorized official institutions such as the police, prosecutors, courts, even prisons, and others are obliged to tackle crime as far as possible. Thus, to be able to overcome acts of sexual violence, it is necessary to enforce the law against perpetrators of sexual violence by giving punishments in accordance with the crimes committed to provide a deterrent effect against them so as to reduce as far as possible the acts of sexual violence against children which very much befall children in Indonesia.

\section{Conclusion}

The essence of criminal responsibility for perpetrators of sexual violence against girls with disabilities is the application of sanctions against perpetrators and protection from the community which is the basic core of the form of respect, promotion, protection, and fulfillment of the dignity of girls with disabilities who are victims of sexual violence.

\section{References}

Aksan, Karim, M. Said., \& Asis, Abdul. (2020). Legal assistance agencies for children as criminal action victims in criminal justice processes. Jurnal Cakrawala Hukum, 11(3), 313-322.

Alfian, A. (2015). Upaya Perlindungan Hukum Terhadap Korban Tindak Pidana Perdagangan Orang. Fiat Justisia: Jurnal Ilmu Hukum, 9(3).

Andriani, N. S. (2017). Kebijakan Responsif Disabilitas: Pengarusutamaan Managemen Kebijakan Di Level Daerah, Nasional Dan Internasional. Palastren Jurnal Studi Gender, 9(1), 189-214.

Anugrianti, A. D., Muchtar, S., \& Azisa, N. (2019). The Concept Of Imposing Criminal Sanctions For Perpetrators Of Child Sexual Violence: The Deterrent Effect. European journal of law and political sciences, (3), 14-19.

Bakhtiar, H. S., Sofyan, A. M., \& Haeranah, H. (2019). Criminal Justice System of Children in Indonesia. IOSR Journal Of Humanities And Social Science (IOSR-JHSS) Volume, 24, 01-07.

Erdianti, R. N., \& Fatih, S. M. (2019). Mewujudkan Desa Layak Anak Sebagai Bentuk Perlindungan Hukum Terhadap Anak Di Indonesia. Justitia Jurnal Hukum, 3(2).

Fadhilah, F. (2020). Tindak Pidana Pelecehan Seksual Oleh Anak Di Bawah Umur Menurut Uu No. 35 Tahun 2015 (Kajian Kasus di Mahkamah Syar'iyah). SYARIAH: Journal of Islamic Law, 2(2), 88-119.

Firdaus, F., \& Iswahyudi, F. (2010). Aksesibilitas Dalam Pelayanan Publik Untuk Masyarakat Dengan Kebutuhan Khusus. Jurnal Borneo Administrator, 6(3).

Fitri, A. N., Riana, A. W., \& Fedryansyah, M. (2015). Perlindungan Hak-Hak Anak Dalam Upaya Peningkatan Kesejahteraan Anak. Prosiding Penelitian dan Pengabdian kepada Masyarakat, 2(1).

Haeranah, H., Azisa, N., Soewondo, S. S., Nur, R., \& Bakhtiar, H. S. (2020). Sanctions Against Children Who Commit Criminal Offense in Indonesia. Tadulako Law Review, 5(1), 76-88.

Irwansyah. (2020). Penelitian hukum : pilihan metode \& praktik penulisan artikel. Yogyakarta: Mirra Buana Media.

Jannah, S. H. M., Muchtar, S., \& Mirzana, H. A. (2021). Restitution rights for children of victims of sexual crimes: between protection and reresting. Jurnal Cakrawala Hukum, 12(2), 223-232.

Mumu, V. A. J. (2019). Tinjauan Yuridis Tentang Tanggung Jawab Orang Tua Terhadap Anak Setelah Perceraian Dalam Uu No 11974 Pasal 45 Ayat (1). Lex Privatum, 6(8).

Nur, F., Akub, M. S., Karim, M. S., \& Muchtar, S. (2019). Legal Protection of Victim Rights against Human Trafficking in the Criminal Justice Process. JL Pol'y \& Globalization, 87, 139.

Nur, R., \& Bakhtiar, H. S. (2020). The Imposition of Sanctions for Children. Hasanuddin Law Review, 6(2), 165171.

Anak. Prosiding Penelitian dan Pengabdian kepada Masyarakat, 2(1).

${ }^{1}$ Panjaitan, S., Siregar, G. T., \& Siregar, S. A. (2021). Peran Bapas Sebagai Pembimbing Kemasyarakatan Dalam Penanganan Anak Yang Berkonflik Dengan Hukum (Studi Pada Bapas Kelas I Medan). Jurnal Retentum, 2(1), 79-89. 
Nur, R., Riza, M., Moenta, A. P., \& Bakhtiar, H. S. (2020). Sanctions on Children: Comparative Studies of Indonesia and Netherlands. JL Pol'y \& Globalization, 98, 225.

Pangemanan, J. B. (2015). Pertanggungjawaban Pidana Anak dalam Sistem Peradilan Pidana Indonesia. Lex et Societatis, 3(1).

Panjaitan, S., Siregar, G. T., \& Siregar, S. A. (2021). Peran Bapas Sebagai Pembimbing Kemasyarakatan Dalam Penanganan Anak Yang Berkonflik Dengan Hukum (Studi Pada Bapas Kelas I Medan). Jurnal Retentum, 2(1), 79-89.

Rahmi, A. (2018). Urgensi Perlindungan Bagi Korbankekerasan Seksual Dalam Sistem Peradilan Pidana Terpadu Berkeadilan Gender. Jurnal Mercatoria, 11(1), 37-60.

Rahmi, A. (2018). Urgensi Perlindungan Bagi Korbankekerasan Seksual Dalam Sistem Peradilan Pidana Terpadu Berkeadilan Gender. Jurnal Mercatoria, 11(1), 37-60.

Said, M. F. (2018). Perlindungan Hukum Terhadap Anak Dalam Perspektif Hak Asasi Manusia. JCH (Jurnal Cendekia Hukum), 4(1), 141-152.

Sianipar, S. R. (2019). Penerapan Hukum Terhadap Pelaku Kekerasan Anak yang Mengakibatkan Kematian Berdasarkan Undang-Undang Nomor 35 Tahun 2014 Tentang Perlindungan Anak (Studi Kasus Putusan No. 560/Pid. Sus/2016/PN. Mdn). Universitas Medan Area.

Soekanto, S., \& Mamudji, S. (2014). Penelitian Hukum Normatif Suatu Tinjauan Singkat, cet. 16. Jakarta: Rajawali Pers.

Supriyanto, B. H. (2015). Perlindungan Hukum Terhadap Anak Pelaku Perkosaan Berdasarkan Hukum Positif Indonesia. ADIL: Jurnal Hukum, 6(2), 147-181.

Tengker, O. R. (2021). Perlindungan Khusus Bagi Anak Korban Kekerasan Fisik Atau Psikis. Lex Privatum, 9(4).

Wiarti, J. (2020). Kompleksitas Persoalan Pemenuhan Hak Penyandang Disabilitas di Pengadilan Negeri Pekanbaru. Jurnal Hukum Ius Quia Iustum, 27(1), 87-109.

Widinarsih, D. (2019). Penyandang disabilitas di indonesia: perkembangan istilah dan definisi. Jurnal Ilmu Kesejahteraan Sosial (Journal of Social Welfare), 20(2).

Wulandari, R., \& Suteja, J. (2019). Konseling Pendidikan Seks dalam Pencegahan Kekerasan Seksual Anak (KSA). Prophetic: Professional, Empathy and Islamic Counseling Journal, 2(1), 61-82.

Yulia, R. (2010). Viktimologi: Perlindungan Hukum Terhadap Korban Kejahatan. Yogyakarta: Graha Ilmu. https://www.kemkes.go.id/, accessed on 8 October 2019.

https://www.komnasperempuan.go.id/file/CatataTahunanKekerasanTerhadapPerempuan2019.pdf accessed on 17 October 2019 